\title{
[gw22-e0668] ANTI-APOPTOSIS EFFECTS OF CAPTOPRIL, MILKVETCH ROOT AND THEIR COMBINATION ON HUVEC INDUCED BY $\mathrm{H}_{2} \mathbf{O}_{2}$
}

Zhang Jing, He Shenghu Jiangsu Province Subei Renmin Hospital, Jiangsu, China

10.1136/heartjnl-2011-300867.226

Objective To investigate the protective effects and mechanisms of ACEI (Captopril), Milkvetch root and their combination on human umbilical vascular endothelial cells (HUVECs) following the damage of hydrogen peroxide $\left(\mathrm{H}_{2} \mathrm{O}_{2}\right)$.

Methods HUVEC were injured for $4 \mathrm{~h}$ by $2.00 \mathrm{mmol} / 1 \mathrm{H}_{2} \mathrm{O}_{2}$ after they were incubated with different dosages of Captopril, Milkvetch root and their combination for $24 \mathrm{~h}$. AO/EB fluorescent staining observed morphology changing of apoptosis. Apoptosis ratio of HUVEC was detected by FCM. Important inhibition apoptosis proteinum Bcl-2 was detected by Western blot.

Results The morning apoptosis ratio of cell in the normal control and (Captopril-L, M, H/Milkvetch root-M, H) $+\mathrm{H}_{2} \mathrm{O}_{2}$ groups were significantly lower than those in the $\mathrm{H}_{2} \mathrm{O}_{2}$ oxidative control $(p<0.05$ or $p<0.01)$ except Milkvetch root- $\mathrm{L}+\mathrm{H}_{2} \mathrm{O}_{2}$ group ( $>0.05)$. The total apoptosis ratio of cell in the normal control and (Captopril/Milkvetch root-M, $\mathrm{H}$ ) $+\mathrm{H}_{2} \mathrm{O}_{2}$ groups were significantly lower than those in the $\mathrm{H}_{2} \mathrm{O}_{2}$ oxidative control $(p<0.05$ or $p<0.01)$ except Captopril/Milkvetch root$\mathrm{L}+\mathrm{H}_{2} \mathrm{O}_{2}$ group ( $p>0.05$ ). Besides the content of important inhibition apoptosis proteinum Bcl-2 of cell in the normal control and (Captopril/Milkvetch root-M, $\mathrm{H})+\mathrm{H}_{2} \mathrm{O}_{2}$ groups were significantly lower than those in the $\mathrm{H}_{2} \mathrm{O}_{2}$ oxidative control $(\mathrm{p}<0.05$ or $\mathrm{p}<0.01)$ except (Captopril/Milkvetch root $-\mathrm{L})+\mathrm{H}_{2} \mathrm{O}_{2}$ group ( $p>0.05)$. The effect of (Captopril+Milkvetch root)-L, $\mathrm{M}, \mathrm{H}+\mathrm{H}_{2} \mathrm{O}_{2}$ groups were significantly better than those in the Captopril/Milkvetch root- $\mathrm{L}, \mathrm{M}, \mathrm{H}+\mathrm{H}_{2} \mathrm{O}_{2}$ groups $(\mathrm{p}<0.05$ or $\mathrm{p}<0.01)$. Conclusion Captopril, Milkvetch root and their combination can decrease in the morning and apoptosis ratio induced by $\mathrm{H}_{2} \mathrm{O}_{2}$, increases the level of proteinum Bcl-2 of cell, and depends on their concentration to some extent. The combined effect of Captopril and Milkvetch root is better than the single effect of Captopril and Milkvetch root. So the combination of Medicine and Chinese traditional medicine can better protect damaged HUVECs. 